\title{
Assessment of an energy-efficient metal chulha for solid biomass fuel and evaluation of its performance
}

\author{
M. Baqir ${ }^{1}$ S. K. Bharti ${ }^{1} \cdot$ R. Kothari ${ }^{2} \cdot$ R. P. Singh ${ }^{1}$
}

Received: 9 March 2018 / Revised: 30 August 2018 / Accepted: 24 September 2018 / Published online: 1 October 2018

(c) The Author(s) 2018

\begin{abstract}
The present study evaluates the performance of a newly developed improved metal chulha (IMC) over available traditional mud chulha (TMC) as an energy-efficient nonsmoking cooking appliance for the rural households. An extensive survey of 90 respondents revealed that majority of the households use firewood for cooking in energy-inefficient TMCs. The TMC emitted considerable amount of toxic component, which can adversely affect the human health on direct exposure. To overcome this problem, we have developed an IMC, which significantly reduces energy loss and cooking time compared to TMC. In this study, we have measured the level of airborne pollutants emitted from fuelwood used for cooking purpose. In addition to this, we have also studied the thermal efficiency of IMC over TMC. A major reduction in indoor pollutants viz. $\mathrm{PM}_{10}$ (45\%), $\mathrm{PM}_{2.5}$ (73\%), $\mathrm{CO}(51 \%), \mathrm{SO}_{\mathrm{X}}(22 \%), \mathrm{NO}_{\mathrm{X}}(36 \%)$ was recorded for IMC over the TMC. The water boiling test also indicates higher thermal efficiency during all the three phases: cold start (37\%), hot start (41\%) and simmering test (46\%) for IMC over TMC. The fuel consumption rate $\left(\mathrm{g} \mathrm{min}^{-1}\right)$ was recorded 23, 16.6, 14 and 32.2, 25.1 and 20.6 for IMC and TMC, respectively. Compared with TMC, the IMC reduced specific fuelwood consumption, increased efficiencies and lower emissions of pollutants including $\mathrm{PM}_{10}, \mathrm{PM}_{2.5}, \mathrm{NO}_{\mathrm{X}}, \mathrm{SO}_{\mathrm{X}}$ and $\mathrm{CO}$. A social survey in the form of a questionnaire revealed that majority of households realized that IMC will be better than the TMC in terms of handling, reduced emissions, easier cooking and efficiency.
\end{abstract}

Keywords Chulha $\cdot$ Fuelwood $\cdot$ Pollution $\cdot$ Thermal efficiency

\section{Introduction}

Biomass is one of the largest and important energy sources in domestic cooking of rural area of developing countries and used frequently for heating purposes in the extreme cold as a fuel (Bonjour et al. 2013). In India, majority of the households living in a rural area depend on fuel wood, dung cake and crops residue to meet their domestic energy needs and these solid fuels account for more than $80 \%$ of total fuel used for cooking purposes (India Census 2011).

Editorial responsibility: U.W. Tang.

\section{R. P. Singh}

pratprana275@gmail.com

1 Department of Environmental Science, Babasaheb Bhimrao Ambedkar (Central) University, Raebareli Road, Lucknow, UP 226025, India

2 Department of Environmental Science, Central University of Jammu, Samba, J\&K 181143, India
Due to high cost and low accessibility of commercial fuels such as kerosene and LPG, rural population uses such easily available traditional fuel (Balakrishnan et al. 2004). Cooking and heating with dried biomass release toxic pollutants in the indoor environment (Herbert and Krishnan 2016). The inefficient way to burn solid biomass fuel releases a large amount of air pollutants, including fine particles $\left(\mathrm{PM}_{10}\right.$ and $\left.\mathrm{PM}_{2.5}\right)$ and gaseous pollutants $\left(\mathrm{CO}, \mathrm{SO}_{\mathrm{X}}\right.$ and $\left.\mathrm{NO}_{\mathrm{X}}\right)$ that present a high environmental risk (GBD 2016 Risk Factors Collaborators 2017; Arora et al. 2013; Suresh et al. 2016). Exposure to indoor air pollution causes serious health risks, especially to women, who cook food and children who spend much time around the cooking chulha with their mothers (Singh et al. 2014). Among these carbon monoxide (CO) emitted by the incomplete combustion of low-quality solid fuel in indoor and semi-interior kitchens, which can become lethal for occupants (WHO 2010; Ezzati et al. 2010), suspended particulate matter $\left(\mathrm{PM}_{10}\right.$ and $\left.\mathrm{PM}_{2.5}\right)$ that can travel deep into the respiratory system results in serious health problems. Exposure of $\mathrm{PM}_{2.5}$ alone accounted about three 
million deaths annually (WHO 2014). It has been estimated that more than four million people residing mostly in rural areas die annually from exposure to indoor air pollution and a quarter of these deaths occur alone in South Asia (WHO 2014; WHO 2016). Therefore, switching to cleaner fuel is one of the promising strategies for improving indoor air quality (Grieshop et al. 2011). The inefficient biomass combustion for cooking also contributes to the level of global $\mathrm{CO}_{2}$ emission significantly (Smith et al. 2005; Chafe et al. 2014).

Traditional one-pot or two-pot mud chulha has low thermal efficiency and huge emission of smoke as compared to the improved cookstoves (Panwar and Rathore 2008). The government of India has initiated several programs focusing on improved cookstove, biogas plant, kerosene and energy supply, aimed to reduce the dependence on biomass fuel and reduction in emission of smoke since the early eighties (Hanber and Karve 2002). Although the evaluation of success is not analyzed properly, recently, different initiatives have been carried out at the grass roots levels and a wide infrastructure has been created to implement projects to overcome the problems related to indoor air pollution. National program of improved cookstove (NPIC 1985-2000) aims to achieve conservation of fuelwood and reduction in emissions in the indoor kitchen by the use of chimney system, but the success has remained elusive (Khandelwal et al. 2017).

Currently, more than 160 improved cookstove programs are operating worldwide (Gifford 2010; Ruiz-Mercado et al. 2011). Some of the prominent energy-efficient biomass cookstoves such as natural and forced draft cookstove, plancha cookstove, rocket mud stove, Patsari improved cookstove and other improved cookstoves have been developed to alleviate the problems associated with indoor pollution and thermal performance (Grandersona et al. 2009; Venkataraman et al. 2010; Caroline et al. 2013; Suresh et al. 2016). However, these improved chulhas have certain limitation in their thermal performance, risk to fire spark, ash collection system for proper disposal. In some chulhas, we cannot cook two or more items at the same time and also not much significant reduction in emissions has been reported (Jetter et al. 2012; Arora et al. 2013). There is still improvement need in the energy efficiency of these chulhas to reach the LPG-like emission levels. Keeping this and feedback surveys of the selected study areas in consideration, it was found that the developed IMC over TMC with similar design will be more acceptable to the rural people. Therefore, the objectives of the present study were planned as: (a) To develop an improved metal chulha over commonly available traditional mud chulha for rural households; (b) To quantify the reduction in fuelwood use attributable to IMC at household's level compared to TMC; and (c) Characterization of $\mathrm{PM}_{10}$, $\mathrm{PM}_{2.5}$ in terms of particle size distribution and sought to determine the acceptability of the improved metal chulha to local users as well as their effectiveness in reducing indoor concentrations and efficiency. This contribution helps to raise awareness about the need for improvement in design and provides evidence data for policy implication and to switch on improved and better designed cookstoves and better designed for health care of the rural people, their economic concerns and climate benefits.

\section{Materials and methods}

\section{Study site}

Rural area selected for the present study was a village Kahinaur of district Mau, Uttar Pradesh, India, with a geographical coordinate $25^{\circ} 52^{\prime} 274^{\prime \prime} \mathrm{N}$ and $83^{\circ} 30^{\prime} 578^{\prime \prime} \mathrm{E}$. Out of 490 households in the selected study area, 90 households were randomly selected for questioning. Based on the stratified sample, random sampling technique of households was selected for collecting the primary data on several household's level parameters through door-to-door survey of households. Stratification of village on the basis of energy consumption pattern was carried out to collect data from each household through semi-structured questionnaire. Various sets of information on socioeconomic condition, house characteristics, energy consumption pattern and kitchen type used were obtained. The questionnaire was developed on the basis of fuel source, use of fuel type, type of kitchen and cookstove uses. All the primary data were coded, and doubled entry was made. For data cleaning and validation, further analysis through SPSS software was used.

After the survey reports, majority of the households use traditional U-shaped mud chulha for cooking purposes which is thermally inefficient and emission emitted directly into the indoor kitchen environment and exposure to households near the chulha during cooking purposes. So, it is important to concentrate and intervention with improved Chula with innovative design that would be more energy efficient and less emission exposure during cooking purposes and heating. Testing of IMC over TMC was carried out in a simulated village kitchen (length $\times$ width $\times$ height: $4.5 \mathrm{~m} \times 3.5 \mathrm{~m} \times 3.2 \mathrm{~m}$ ) setup in the Kahinaur village of district Mau. The testing site was about $3 \mathrm{~km}$ away from the city and $1 \mathrm{~km}$ from the state highway. Collection of air samples from indoor kitchen was taken during the cooking process. The reason for choosing indoor kitchen sampling method 
Fig. 1 Schematic diagram for the setup of the indoor air sampling during the cooking processes $(R D S$ respiratory dust sampler; FPS fine particulate sampler)

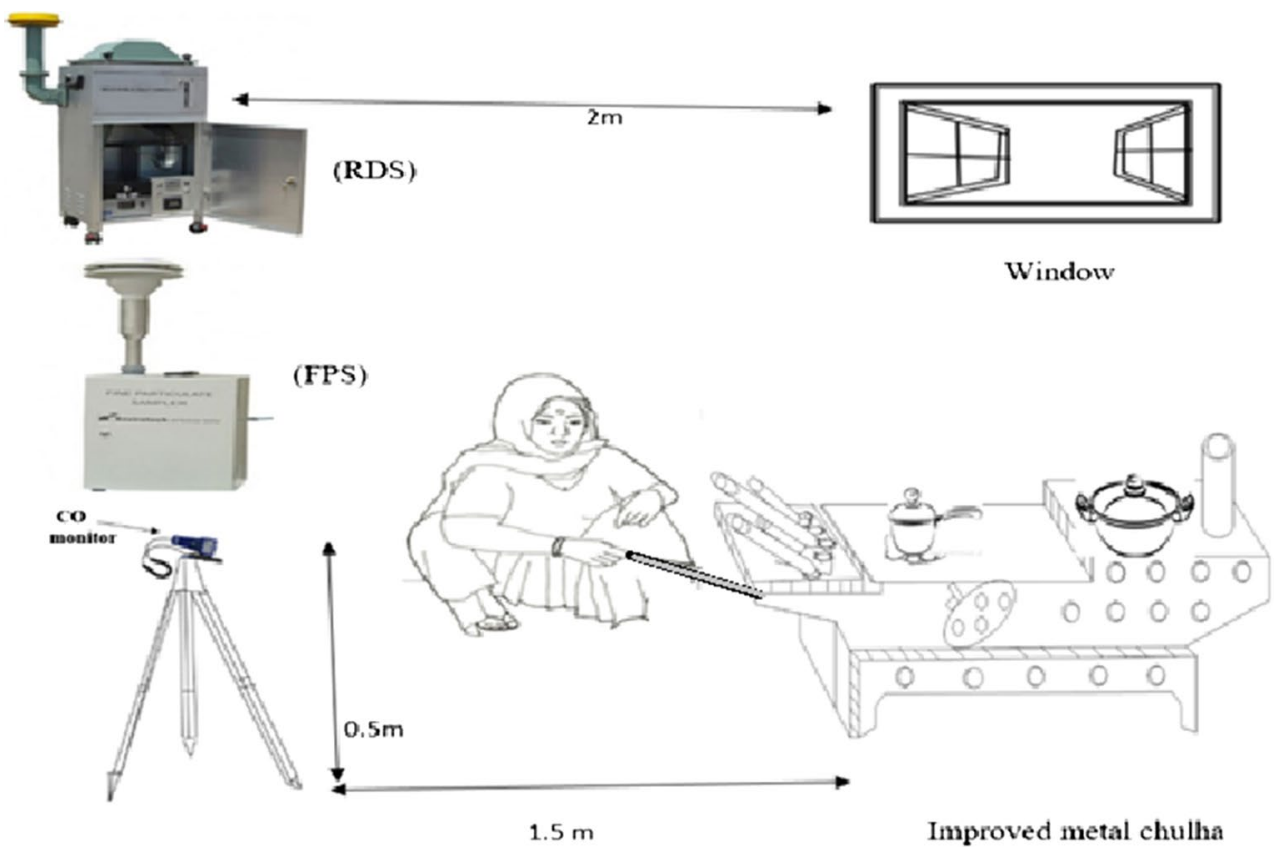

for emission samples because of majority of the households were using similar pattern of indoor kitchen for cooking of daily meals. The air sampler was placed in the kitchen at a distance of one and a half meter away from the combustion zone as shown in Fig. 1. Concentration of a pollutant in the kitchen environment was monitored during the cooking processes. Average time taken to monitor the indoor air quality during the cooking hour was three and half hour because this time is an average time taken to cook the single meal by Indian rural women in the indoor kitchen.

\section{Fuel used}

The most commonly available fuelwood in the study area was Alangium salvifolium, Prosopis Juliflora and Terminalia arjuna. However, for the present study, Prosopis Juliflora was used as a fuel wood. This species was the most preferred species as firewood in the selected region, and its gross calorific value was higher compared to other commonly available species studied. Testing of IMC over TMC was done by using the same size of fuel wood. Before using as fuel, the moisture content of fuelwood was measured by oven-dry method and it varied from 5 to $12 \%$. The average size of wood pieces was made uniform, i.e., $3 \times 3 \times 20 \mathrm{~cm}$ as per specification of IMC and size of burning chamber of the IMC manufactured. The gross calorific value of fuelwood used for water boiling test (WBT) was estimated by digital oxygen bomb calorimeter and was found to be $19.56 \mathrm{MJ} \mathrm{kg}^{-1}$.

\section{Measurement of different parameters during the experiment}

\section{Measurement of $\mathrm{PM}_{10}, \mathrm{PM}_{2.5}, \mathrm{CO}, \mathrm{SO}_{\mathrm{x}}$ and $\mathrm{NO}_{\mathrm{x}}$}

Monitoring of suspended particulate matter and gaseous pollutants $\left(\mathrm{SO}_{\mathrm{X}}, \mathrm{NO}_{\mathrm{X}}\right.$ and $\left.\mathrm{CO}\right)$ was carried out during winter season. A total of 48 samples of coarse particles $\left(\mathrm{PM}_{10}\right)$ were collected onto glass fiber filters $(8 \times 10$ in.) using by respirable dust sampler (Model-APM $460 \mathrm{BL}$, Envirotech) at a flow rate of $1.3 \mathrm{~m}^{3} \mathrm{~min}^{-1}$, while the fine particles $\left(\mathrm{PM}_{2.5}\right)$ were collected on glass microfiber filter paper $(47 \mathrm{~mm})$ using fine particulate sampler (FPS, Envirotech, APM 550) operating at a constant flow rate of $16.67 \mathrm{~L} \mathrm{~min}^{-1}$. The mass concentration in the ambient air is computed as the total mass of collected particles was divided by the actual volume of air sampled and expressed in $\mu \mathrm{g} \mathrm{m}^{-3}$ (Bharti et al. 2017). For measurement of carbon monoxide (CO), a portable electrochemical cell-based CO monitor (Model: Drager Pac III, Draeger Safety Inc., Pittsburgh, USA) was used to measure the concentration of $\mathrm{CO}$ during the cooking hour in the indoor kitchen (Fig. 1). The minimum detectable limit of the instrument was $0.02 \mu \mathrm{g} \mathrm{m}^{-3}$ with $0.01 \mu \mathrm{g} \mathrm{m}^{-3}$ resolution. The instrument was calibrated before the starting of experiment with $910 \mu \mathrm{g} \mathrm{m}^{-3} \mathrm{CO}$ in nitrogen standard (MSC-307; Master Standard, Mumbai, India). Analysis of $\mathrm{SO}_{\mathrm{X}}$ and $\mathrm{NO}_{\mathrm{X}}$ was performed according to the method of Bureau of Indian Standard (BIS) (2001): IS: 5182 (Part II) and Indian Standard (1975): IS: 5182 (Part VI), respectively. 


\section{Trace metal analysis}

The extraction of metals from filter paper was carried out in digestion mixture of nitric acid and perchloric acid (3:1) on the hot plate until the solution becomes clear and reduced to 2-3 mL. Digested samples were filtered through Whatmann filter no. 42 , and final volume was made up to $50 \mathrm{~mL}$ by $0.1 \mathrm{~N}$ nitric acid. The filtrate was examined for the concentration of trace metal by AAS (Varian Spectra AA-250 Plus). The AAS was calibrated for each metal using known CRM (Qualigens make) before analysis (Sharma et al. 2006).

\section{SEM-EDS instrumentation}

Morphological and elemental characterization of airborne particulates were performed by SEM (JSM 6490LV, JEOL) coupled with EDS (Oxford INCA x-act). Dry and particleloaded filters were cut into approximately $1 \mathrm{~mm}^{2}$ size and mounted on aluminum stubs with double-sided sticky carbon tape. A very thin film of gold and palladium was deposited on the surface of the samples to make them electrically conductive using vacuum coating unit. Samples were examined, and photographs were taken at different magnification by stereo SEM at 30 tilt and $10 \mathrm{kV}$. Three images of the single sample were taken at different magnifications to highlight the morphological characteristics. EDS spectra of the individual aerosol particles were obtained by scanning an electron beam with an accelerating voltage of $15-30 \mathrm{kV}$ (Bharti et al. 2017; Sielicki et al. 2011; Srivastava et al. 2009).

\section{Thermal efficiency}

The thermal efficiency of IMC over TMC was evaluated by following the well-defined water boiling test protocol (WBT protocol version 4.1.2) (Lombardi et al. 2017). While there are many other methods for testing cooking stoves used by governments and organizations around the world, the water boiling test was chosen because it has been written and continually revised by the cooperation of international experts in the field. The WBT performed in three phase, i.e., cold start (high-power phase) is the first phase begins with the stove, standard test pot and water at room temperature, and the stove is operated until the water reaches boiling temperature; hot start (high-power phase) is the second phase begins immediately after the first phase with the hot stove and with the pot refilled with water at room temperature. The stove is operated until the water reaches boiling temperature. Results for the cold start and hot start can be compared to identify differences in performance between a cold and hot start, and simmered test (low-power phase) is the third phase begins immediately after the second phase with the stove, pot and water hot. The stove is operated to maintain the water temperature just below the boiling point, and results can be compared to identify differences in performance between low-power and high-power operation of the stove (Fig. 2). Prior to starting the test, approximately $10 \mathrm{~L}$ of water and $15 \mathrm{~kg}$ of dry fuelwood with uniform size must be needed for WBT. Between each of the three phases, the wood, water, temperature and charcoal are weighed by quickly removing and
Fig. 2 Water boiling test procedure

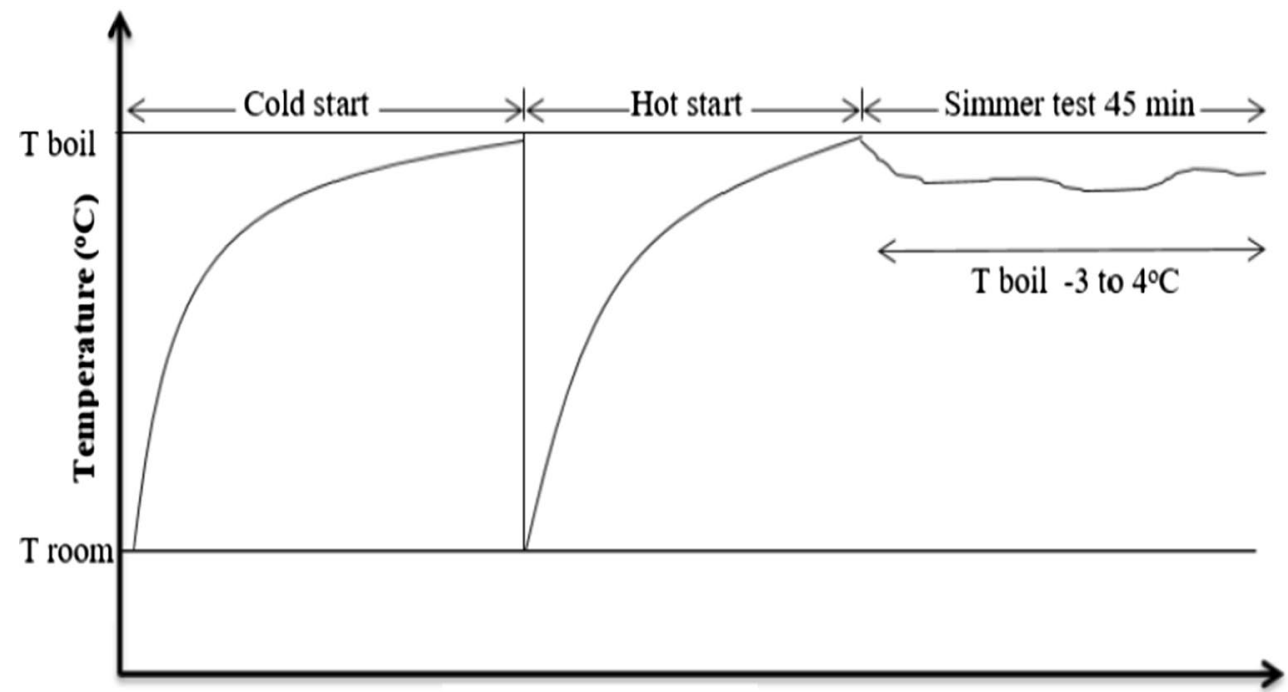

Time in (minutes) 

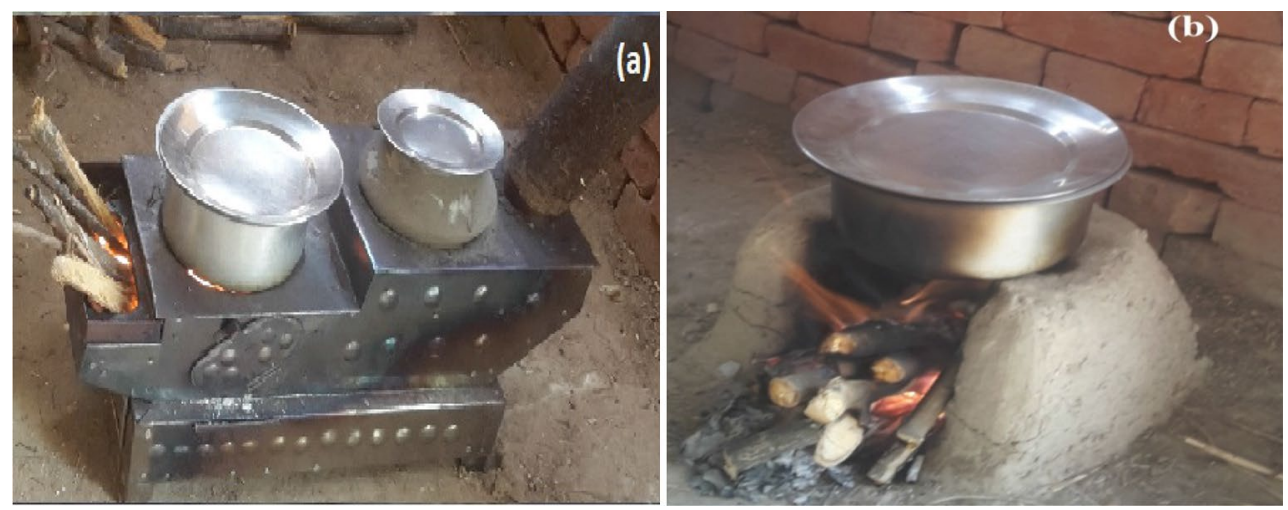

Fig. 3 Types of chulha in rural India: a improved metal chulha (IMC) and $\mathbf{b}$ traditional mud chulha (TMC)

extinguishing the fuel. Burning of biomass in cookstove is highly variable. Therefore, a number of replicates required for the overall performance of cookstove. In the present study, five replicates of WBTs were performed for both types of chulha (IMC vs TMC) to calculate the average performance metrics. These measurements of the cookstove performance at both high- and low-power phase help to simulate what is likely to occur when cooking foods that involve boiling and simmering. This type of cooking is believed to be the most common type of cooking.

\section{Improved metal chulha (IMC)}

Two-pot rectangular metal chulha was developed and tested in present study (Fig. 3a). Based on the survey results of the study area, majority of the households use TMC-like
U-shaped chulha, with an opening in the front to feed the fuel (Fig. 3b). The IMC was developed with a metal foil consisting of the inlet to load solid fuel and air, the combustion chamber, two pot holes and an outlet connected to the chimney system (Fig. 4).

The mean size of IMC is with the dimensions of $65 \mathrm{~cm} \times 35 \mathrm{~cm} \times 40 \mathrm{~cm}$ length $\times$ width $\times$ height. For cooking, diameter of the pot hole is different in size: first pot hole $(25 \mathrm{~cm})$ and second pot hole $(20 \mathrm{~cm})$ to adjust the small- and medium-sized container. The distance between two pot holes is $10 \mathrm{~cm}$. Inside the chulha, a plane inclined between two holes was developed and this structure was intended to direct the heat flame from the combustion chamber of the first pot hole to second pot hole. The grate was developed in the floor of the combustion chamber to filter the ash to the bottom of the ashtray to facilitate
Fig. 4 Improved metal chulha design features: (1) air/fuel inlet; (2) first pot hole; (3) second pot hole; (4) chimney; (5) ashtray; (6) grate plate; (7) side drawer; (8) grate; (9) combustion chamber

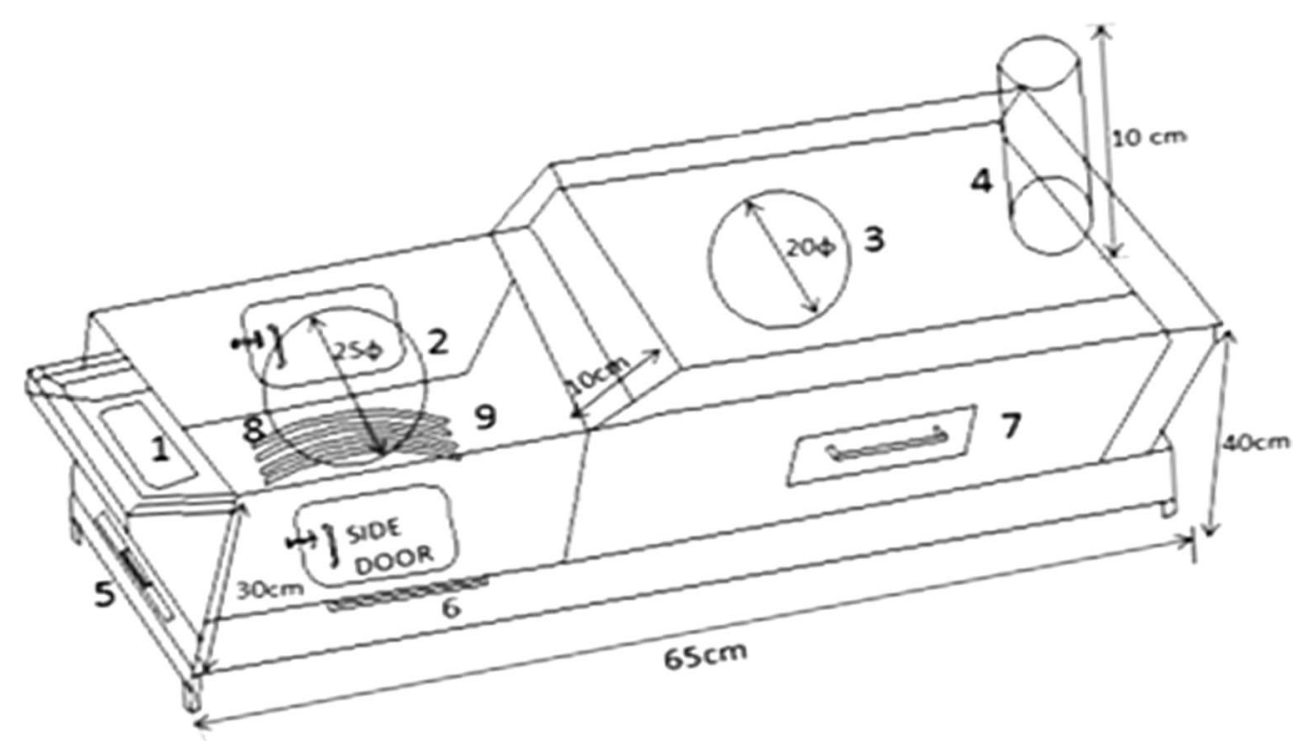


removal of ash that is collected in the tray for the safe disposal after combustion. Alternatively, grate has been used for charcoal as fuels in the absence of solid biomass fuel. Just below the second pot hole, there is another drawer developed for the preparation of cakes and bread during the cooking process. Chimney connected in IMC to facilitate the elimination of smoke from the interior environment. The chulha has a safety lid to minimize the risk of fire spark during cooking. The combustion chamber was designed in such a way that the minimum distance between flame and pot during the cooking processes to minimize energy wastage.

The average cost for manufacturing IMC is INR 1500 to INR 1800. The initial cost would seem to be a major barrier to adoption, particularly for the rural poor population, but it requires a smaller amount of fuelwood compared to TMC and produces a relatively smaller amount of ash and smoke during the cooking process. Hence, costs and benefits of IMC are more advantageous in term of fuel cost, system efficiency, cooking time and most important is respiratory diseases.

\section{Results and discussion}

\section{Survey results}

After an initial survey in each household, it has been noticed that most of the households were low incomes with main occupation either being agriculture self-employment or from labor class. Houses were classified on the basis of kutcha house (uncemented) and pukka houses (cemented house). $60 \%$ of households were kutcha houses having no separate kitchen. Most of the households moderately ventilated by having a door and a window, and about $10 \%$ of the households, kitchen was not having window and hence poorly ventilated. Majority of the households rely on traditional biomass-based fuel (fuel wood, agriculture residue and cow dung) for meeting the energy needs and most of the households collected firewood from the plantation forest near the selected study area for daily energy need. With the help of survey report, maximum households would prefer improved chulha even with high cost in respect of traditional chulha, due to its healthy environment contribution toward. The pattern of energy consumption for cooking in the study area was dominated by the noncommercial source of energy. Households rely primarily on firewood, agricultural waste and cow dung cake for the daily need for energy such as cooking and heating during cold seasons. When studying the pattern of consumption of different biomass fuel, it has been reported that about $65 \%$ of households use firewood as primary source of energy followed by cow dung $22 \%$, agriculture residues $12 \%$ and $1.3 \%$ kerosene. Results of the survey are shown in Fig. 5. In rural India, the main source of energy for low-income households comes from biomass fuel: about $78 \%$ from fuelwood, and about $8 \%$ from agricultural waste which was the next major source of energy; these results were also supported by Ramji et al. (2012). Women of the households mostly spend much time in collecting fuelwood for the daily energy needs from nearby plantation forest. The amount of biomass fuel consumed for cooking depends on the number of factors such as type of food, number of meals per day and stove type used. In addition to this, around $75 \%$ households use TMC for cooking purposes and approximately $90 \%$ of respondents realized that IMC would help to reduce fuelwood consumption and reduce indoor smoke exposure, which was
Fig. 5 Composition of energy consumption categorized into used fuel source, fuel type, type of kitchen and cookstove. Error bar indicates standard error of mean of five replicate observations

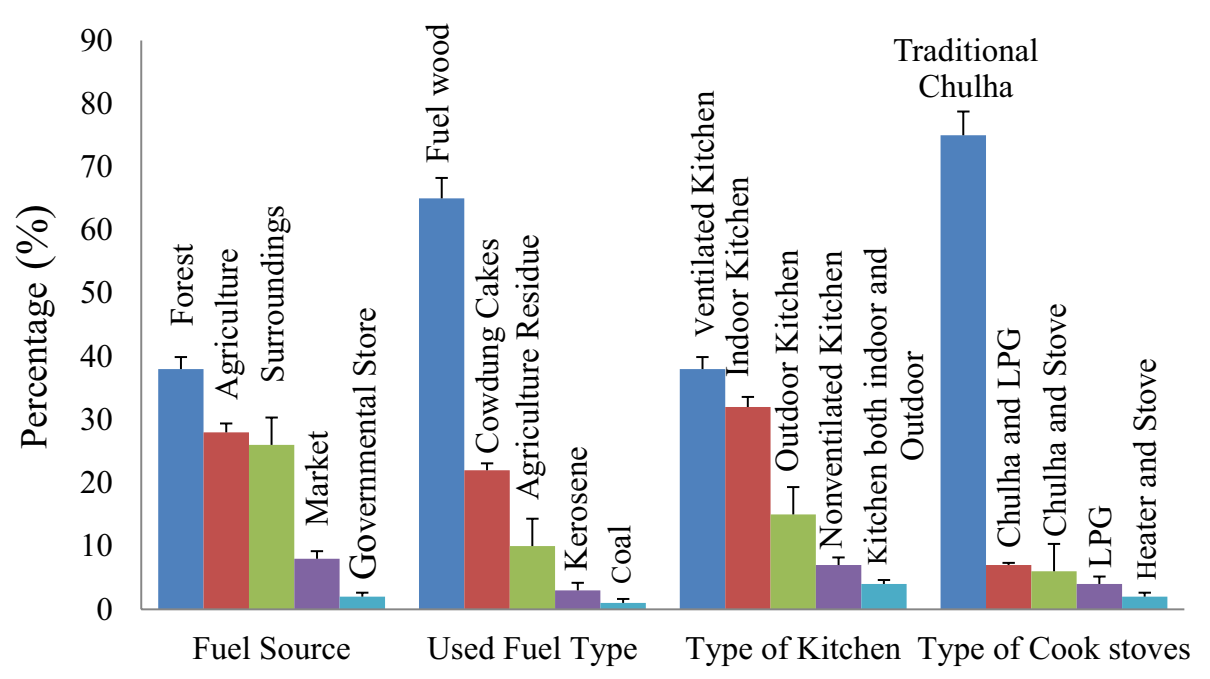


Fig. 6 Comparative evaluation of $\mathrm{NO}_{\mathrm{X}}, \mathrm{SO}_{\mathrm{X}}, \mathrm{PM}_{10}, \mathrm{PM}_{2.5}$ in $\mu \mathrm{g} \mathrm{m}^{-3}$ and $\mathrm{CO}$ in $\mathrm{mg} \mathrm{m}^{-3}$ of improved metal chulha (IMC) over traditional mud chulha (TMC). Bars indicate mean of three replicate observations. Error bar at the top of the mean bars indicates standard error of mean

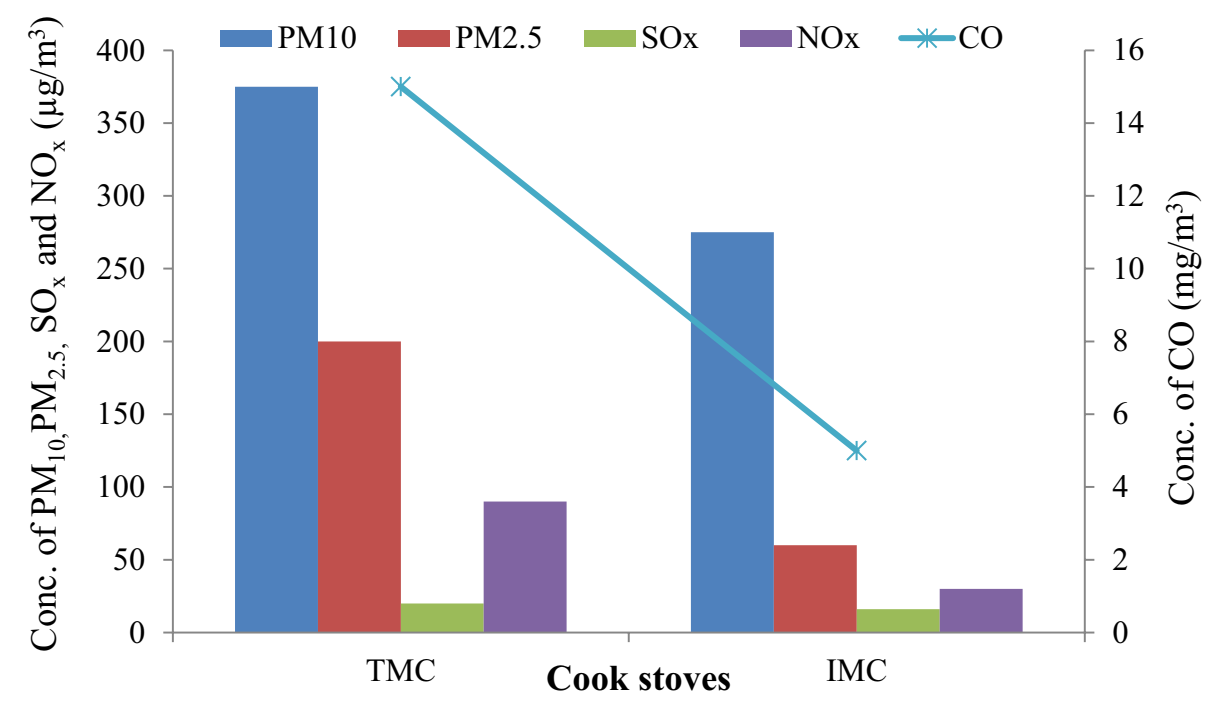

associated with reduced respiratory problems, eye irritation and other problems of health.

\section{Variation in different parameters of traditional versus improved metal chulha}

\section{Variation in $\mathrm{PM}_{10}, \mathrm{PM}_{2.5}, \mathrm{CO}, \mathrm{SO}_{\mathrm{X}}$ and $\mathrm{NO}_{\mathrm{X}}$}

Exposure to indoor air pollution depends primarily on the concentration of airborne pollutants and the time that individuals are exposed to the pollutants. However, both shortand long-term exposure can have a significant impact on an individual's health. The variation in the indoor air concentration of different parameters in the present investigation is shown in Fig. 7. A significant reduction in the concentration of $\mathrm{PM}_{10}, \mathrm{PM}_{2.5}, \mathrm{CO}, \mathrm{SO}_{\mathrm{X}}$ and $\mathrm{NO}_{\mathrm{X}}$ in the kitchen environment was observed due to the installation of IMC over TMC (Fig. 6). After the use of IMC, there was a significant reduction in the concentration of indoor air pollutant, i.e., $\mathrm{PM}_{10}$ $44.90 \%, \mathrm{PM}_{2.5} 73.09 \%, \mathrm{CO} 50.86 \%, \mathrm{SO}_{\mathrm{X}} 21.99 \%$ and $\mathrm{NO}_{\mathrm{X}}$
$35.76 \%$. So, IMC is considered to be significant pollutionfree device/system compared to TMC. Newly designed IMC has the properties for the complete combustion and rapid movement of gases and particulates in suspension from the combustion chamber to the chimney for the discharge of smoke at higher altitudes. The reduction in the levels of pollutants transported by the air in the indoor environment may be due to a good compaction without smoke leakage and to an adequate handling of the ash collection system for its proper disposal. In comparison with IMC, Patsari stove also reduces particulate matter by up to $71 \%$ in Mexico (Berrueta et al. 2017). A significant reduction in the indoor concentration of $\mathrm{PM}_{2.5}$ and $\mathrm{CO}$ was reported in Ghana and Ethiopia, where improved wood stove $\left(\mathrm{PM}_{2.5} ; 52 \%\right.$ and $\left.\mathrm{CO} ; 40 \%\right)$ and ethanol stove $\left(\mathrm{PM}_{2.5} ; 84 \%\right.$ and $\left.\mathrm{CO} ; 76 \%\right)$ significantly decrease the levels of airborne pollutants (Pennise et al. 2009). Compared with the traditional cookstove in northern India (Sultanpur, Uttar Pradesh), $\mathrm{PM}_{2.5}$ and $\mathrm{CO}$ concentrations decreased significantly by $21-57 \%$ and $30-74 \%$, respectively, by using forced draft cookstove (Suresh et al.
Table 1 Metal concentration $\left(\right.$ mean $\pm \mathrm{SD}$ ) in $\mathrm{PM}_{10}$ and $\mathrm{PM}_{2.5}$ measured at indoor environment during the cooking process with TMC and IMC

\begin{tabular}{|c|c|c|c|c|c|c|}
\hline \multirow{2}{*}{$\begin{array}{l}\text { Metal Conc. } \\
\left(\mu \mathrm{g} \mathrm{m}^{-3}\right)\end{array}$} & \multicolumn{3}{|l|}{$\mathrm{PM}_{10}$} & \multicolumn{3}{|l|}{$\mathrm{PM}_{2.5}$} \\
\hline & IMC & TMC & (\%) Reduction & IMC & TMC & (\%) Reduction \\
\hline $\mathrm{Fe}$ & $1.15 \pm 0.23$ & $1.69 \pm 0.41$ & $32.1 \pm 0.2$ & $0.76 \pm 0.32$ & $0.986 \pm 0.52$ & $22.4 \pm 0.32$ \\
\hline $\mathrm{Pb}$ & $0.57 \pm 0.72$ & $0.70 \pm 0.23$ & $18.6 \pm 0.3$ & $0.35 \pm 0.87$ & $0.415 \pm 0.43$ & $13.9 \pm 0.76$ \\
\hline $\mathrm{Cu}$ & $0.10 \pm 0.31$ & $0.14 \pm 0.76$ & $22.6 \pm 0.1$ & $0.07 \pm 0.97$ & $0.08 \pm 0.87$ & $18.1 \pm 0.12$ \\
\hline $\mathrm{Cd}$ & $0.02 \pm 0.41$ & $0.04 \pm 0.87$ & $52.0 \pm 0.6$ & $0.02 \pm 0.87$ & $0.03 \pm 0.32$ & $15.6 \pm 0.92$ \\
\hline $\mathrm{Cr}$ & $0.20 \pm 0.32$ & $0.33 \pm 0.75$ & $38.8 \pm 0.1$ & $0.13 \pm 0.23$ & $0.16 \pm 0.11$ & $21.0 \pm 0.43$ \\
\hline $\mathrm{Mn}$ & $0.18 \pm 0.65$ & $0.40 \pm 0.32$ & $55.0 \pm 0.2$ & $0.10 \pm 0.32$ & $0.10 \pm 0.98$ & $05.6 \pm 0.98$ \\
\hline $\mathrm{Zn}$ & $0.36 \pm 0.95$ & $0.62 \pm 0.34$ & $41.2 \pm 0.7$ & $0.45 \pm 0.53$ & $0.64 \pm 0.54$ & $29.5 \pm 0.67$ \\
\hline As & $0.01 \pm 0.64$ & $0.03 \pm 0.64$ & $52.2 \pm 0.6$ & $0.015 \pm 0.64$ & $0.028 \pm 0.64$ & $44.9 \pm 0.46$ \\
\hline
\end{tabular}


2016). In another study, in northern India, improved cooking reduces the concentration of gaseous particles and pollutants $\left(\mathrm{SO}_{\mathrm{X}}\right.$ and $\left.\mathrm{NO}_{\mathrm{X}}\right)$ by $47 \%$ and $55 \%$, respectively (Singh et al. 2014). Reduction in the concentration of indoor emissions through the installation of improved chulha varied on the basis of technical specifications and the use of material for insulation to reduce heat loss (Raman et al. 2013; Suresh et al. 2016). Other studies reported that installation of improved cookstove is considered to perform much better than the traditional stove in terms of both thermal efficiency and reduction in pollution emissions (Arora et al. 2013; Medina et al. 2017). Therefore, strategies to improve indoor air quality generally focus on improved burning of fuelwood by using an efficient cookstove that can help to reduce indoor pollution.

\section{Estimation of trace metals}

In the present study, concentration of trace metals $(\mathrm{Fe}, \mathrm{Pb}$, $\mathrm{Cu}, \mathrm{Cd}, \mathrm{Cr}, \mathrm{Mn}, \mathrm{Zn}$ and $\mathrm{As}$ ) present in $\mathrm{PM}_{10}$ and $\mathrm{PM}_{2.5}$ emitted by two type of chulha is depicted in Table 1 . The trace metal associated with $\mathrm{PM}_{10}$ was found to be in order of $\mathrm{Fe}$ $>\mathrm{Pb}>\mathrm{Zn}>\mathrm{Cr}>\mathrm{Mn}>\mathrm{Cu}>\mathrm{Cd}>\mathrm{As}$ in $\mathrm{IMC}$ and $\mathrm{Fe}>\mathrm{Pb}>$ $\mathrm{Zn}>\mathrm{Cr}>\mathrm{Mn}>\mathrm{Cu}>\mathrm{Cd}>\mathrm{As}$ in TMC. However, the trace metals associated with $\mathrm{PM}_{2.5}$ were found in order of $\mathrm{Fe}>\mathrm{Z}$ $\mathrm{n}>\mathrm{Pb}>\mathrm{Cr}>\mathrm{Mn}>\mathrm{Cu}>\mathrm{Cd}>$ As in both IMC and TMC. The concentration of trace elements associated with fine particles $(\mathrm{Pb}, \mathrm{Cu}, \mathrm{Cd}, \mathrm{Cr}, \mathrm{Mn}$ and $\mathrm{Zn})$ turned out to be very low in comparison with crustal trace metals (Fe), but direct inhalation of these trace metals considered to be hazardous to human health (Taner et al. 2013; Wang et al. 2006; Olujimi et al. 2015). Furthermore, it is also confirmed that most toxic trace metals adhere to fine particles can cause inflammation in the lungs, increases the rate of heartbeat and ultimately reduces the immune response to toxic components (Morman and Plumlee 2013; Pardo et al. 2015; Kim et al. 2016). Installation of IMC showed a significant reduction in the concentration of trace metals associated with coarse and fine particles (Table 1). In the present investigation, it has been found that the concentration of trace metals was found to be higher due to the burning of fuelwood in TMC, whereas IMC significantly reduces the levels of trace metals in indoor environment. Trace metals associated with coarser particles in indoor environment were expected due to the abundance of iron as one of the main components of the earth's crust (Wang et al. 2006; Singh et al. 2008). In case of Pb, ingestion by eating contaminated food or vegetables and cooking food in containers containing lead or lead-based ceramics can raise human $\mathrm{Pb}$ levels (Ming-Ho 2005; Morais et al. 2012). Elevated levels of $\mathrm{Pb}$ can damage the nervous system, digestive system, and in some cases cause cancer (Morais et al. 2012). Trace metals (As, $\mathrm{Pb}, \mathrm{Cd}$ and $\mathrm{Cr}$ ) associated with fine
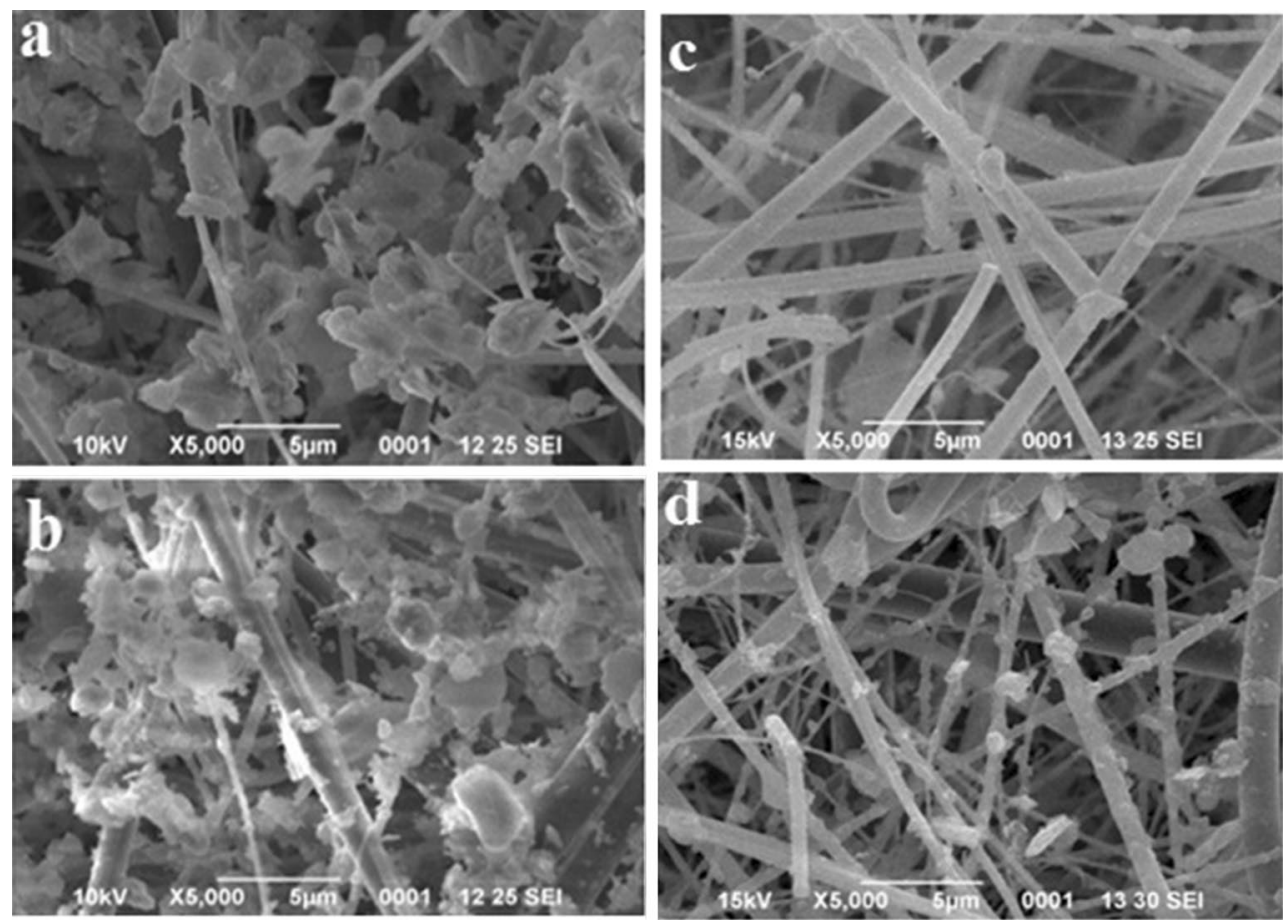

Fig. 7 SEM micrograph of air borne particles: a PM $\mathrm{PM}_{10}$ (TMC), b $\mathrm{PM}_{2.5}$ (TMC), $\mathbf{c} \mathrm{PM}_{10}$ (IMC), $\mathbf{d} \mathrm{PM}_{2.5}$ (IMC) 
Table 2 A performance indicator of improve metal chulha (IMC) over traditional mud chulha (TMC) during different phases of water boiling test (mean \pm standard error)

\begin{tabular}{|c|c|c|c|c|c|c|}
\hline \multirow[t]{2}{*}{ Parameters } & \multicolumn{3}{|l|}{ IMC } & \multicolumn{3}{|l|}{ TMC } \\
\hline & Cold start & Hot start & Simmer test & Cold start & Hot start & Simmer test \\
\hline Fuelwood consumption $\left(\mathrm{g} \mathrm{min}^{-1}\right)$ & $23.65 \pm 2.23$ & $16.63 \pm 3.10$ & $14.76 \pm 4.13$ & $32.21 \pm 2.32$ & $25.16 \pm 2.95$ & $20.66 \pm 5.45$ \\
\hline Thermal efficiency (\%) & $37.32 \pm 1.02$ & $41.24 \pm 2.32$ & $46.42 \pm 3.64$ & $26.42 \pm 3.01$ & $38.43 \pm 3.43$ & $45.52 \pm 3.35$ \\
\hline Time to boil & $14.67 \pm 1.24$ & $12.54 \pm 3.79$ & $30.15 \pm 4.42$ & $20.56 \pm 3.81$ & $15.67 \pm 4.54$ & $30.91 \pm 3.64$ \\
\hline Firepower $(\mathrm{kW})$ & $4.82 \pm 1.60$ & $7.35 \pm 3.10$ & $5.162 \pm 2.70$ & $4.753 \pm 2.40$ & $5.243 \pm 2.80$ & $4.321 \pm 3.10$ \\
\hline
\end{tabular}

particles are carcinogenic in indoor or outdoor environment (Hieu and Lee 2010; Mansour and Alghamdi 2016). Therefore, the present study suggested that the development of energy-efficient chulha can be used to reduce airborne toxins to minimize health risks. In this regard, traditional mud chulha (TMC) has been found to be more common in use in selected study area along with a lot of health issues, fuel issues, low efficiency with cooking time and environmental problems. So, in search of solutions for these problems, this improved metal chulha (IMC) is framed and designed on consideration with specific dimensions. After experimental evaluation in comparison with TMC, a remarkable finding was noticed in terms of low fuel consumption, less emission rates, less cooking time due to high thermal efficiency with less/no contribution toward respiratory diseases and clean indoor environment. Similarly, health risks related to metal composition in the indoor environment should be evaluated more thoroughly in a future study.

The studied morphological features of the selected samples $\mathrm{PM}_{10}$ and $\mathrm{PM}_{2.5}$ allowed us to identify the shapes of particulate matter emitted into the indoor air. It is determined that the particulate matter have a rounded, irregular, cubic and composite shape. In order to differentiate the physicochemical characteristics of particulate matter emitted from IMC and TMC, scanning electron microscope (SEM) micrograph of both fraction of particulate matter has been investigated in this study. Figure $7 \mathrm{a}-\mathrm{d}$ shows representative images for IMC and TMC at 5000X magnification. Using secondary electron imaging, individual particles were classified into two categories viz. soot and aluminosilicates. Soot particles were found to be dominant in a coarser fraction of particulate matter followed by aluminosilicates which were emitted from TMC as shown in Fig. 7b, whereas aluminosilicates followed by soot particles were to be dominant in a coarser fraction of particulate matter emitted from IMC. Soot exhibits chain-like nonfractal agglomerate of the carbonaceous particle, whereas aluminosilicates exhibit nonspherical having sharp edge-like structure (Murari et al. 2016; Bharti et al. 2017). The morphology of the soot particles varied from chains to simple clusters, with a size of $1-2 \mu \mathrm{m}$ that depends on different types of fuels, combustion conditions and atmospheric processes (Yue et al. 2006). These particles are primarily emitted from burning of biomass, and incomplete solid fuel combustion is mainly composed of fine particles and has attracted special attention now a day, mainly due to their contribution to changing climate, reduced visibility and adverse effects on human health (Pipal et al. 2014). The fly ash particles contain mainly aluminosilicates characterized by silicon with varying amount of magnesium, potassium, calcium and iron. These particles originate from the combustion of firewood, and the size ranges of the fly ash particles are between 50 and $1 \mu \mathrm{m}$, with an amorphous, spherical and irregular shape (Lu et al. 2011). Aluminosilicates have a higher content of $\mathrm{Al}, \mathrm{Si}$ and $\mathrm{K}$ and have originated from indoor activities during the cooking processes. These particles contain predominantly silicon such as silica or quartz that originates in soil and crust (Cong et al. 2010). The analysis of the composition in morphological and elementary particles provides valuable information for the determination of its physicochemical properties and diverse sources. This analysis is also essential for the evaluation of the health and ecological effects of indoor air particles.

\section{Thermal efficiency using water boiling test (WBT)}

Thermal performance of IMC over the available TMC was tested by using the three phases of WTB (cold start, hot start and simmering test), and the thermal efficiency was ranged from 37 to $46 \%$ for IMC and $26-45 \%$ for TMC. The average rate of fuelwood burn per minute, thermal efficiency and time are brought to boiling for both the cold start and hot start phases of the IMC and TMC showed that IMC showed highest thermal efficiency during all the three phases: cold start (37\%), hot start (41\%) and simmering (46\%) at the rate of burning of fuelwood was 23, 16.6 and $14 \mathrm{~g} \mathrm{~min}^{-1}$ and in TMC the thermal efficiency was cold start (26\%), hot start $(38 \%)$ and simmering phases (45\%) at the rate of burning of fuelwood was $32.2,25.1$ and $20.6 \mathrm{~g} \mathrm{~min}^{-1}$. In simmering test, there was not much significant difference in the thermal 
efficiency of IMC over TMC (Table 2). However, in both types of chulha, there is an increasing trend of higher thermal efficiency and lower consumption of wood during the three phases of WTB (cold $<$ hot $<$ simmering). The specific fuelwood consumption is a preferable parameter to evaluate simmering performance (Lombardi et al. 2017). Five trails of WBT were carried out in the present investigation for both IMC and TMC and showed that the thermal performance of IMC was recorded higher than TMC. Lower efficiency of TMC may be attributed to higher consumption of fuel wood. Other studies (Panwar et al. 2011; Mehetre et al. 2016) reported that the thermal efficiency of the improved cookstove showed $26.5-30.83 \%$, which is much lower than the thermal efficiency of IMC in the current results. Average time required to boil the specific amount of water in the improved cookstove showed lower as compared to the traditional chulha in both cold and hot start, which was similar value reported by previous researchers also (Bailis et al. 2007; Jetter and Kariher 2009). The difference observed in the thermal efficiency of two types of chulha can also be attributed to the effective design of the combustion chamber and the air flow to the combustion chamber. The fair power indicates the ratio of wood energy consumed by cookstove per unit time. It tells the average power output of the cookstove (in watts) during the WBT.

\section{Conclusion}

The present work evaluates the thermal efficiency and reduction in airborne pollutants by improved metal chulha over commonly available traditional mud chulha in the rural households of India. Installation of IMC enhances the thermal efficiency with the reduction in specific amount of fuelwood consumption in the present investigation. This further reduced the duration of time and the amount of fuel to prepare a particular amount of food. By encouraging the complete combustion of fuelwood in IMC, it reduces the concentration of indoor air emission, which reflects the lower concentration of pollutants into the indoor kitchen environment. Based on the results of the survey, almost all respondents realized that IMC would help to reduce fuelwood consumption and less exposure to smoke, especially women responsible for daily cooking in the indoor kitchen. Hence, the present study suggests that distribution of IMC among rural households in order to improve their health conditions should be a part of government policies for healthy environmental conditions. Further, knowledge should be imparting or focusing more about the use of IMC and its benefits for the reason that societies progress only if their people are healthy, and the government should launch programs on the basis of a different scheme for adaptation of energy-efficient chulha. Therefore, the national-level program must be implemented by the government and the nongovernment organization to introduce this type of IMC. The IMC is not only beneficial to health and the environment but also indirectly responsible for minimizing deforestation and the restoration of deterioration of ecosystem.

Acknowledgement The first author is grateful to UGC, New Delhi, for providing the national fellowship for higher education for conducting the research smoothly. The authors are thankful to Dr. S.C Barman (Senior Principal Scientist: Environmental Toxicology, CSIR-Indian Institute of Toxicology Research Vishvigyan Bhavan, 31, Mahatma Gandhi Marg, Lucknow-226 001. Uttar Pradesh, India) for providing necessary facilities during the testing of chulha and constant help during the indoor air sampling.

Open Access This article is distributed under the terms of the Creative Commons Attribution 4.0 International License (http://creativeco mmons.org/licenses/by/4.0/), which permits unrestricted use, distribution, and reproduction in any medium, provided you give appropriate credit to the original author(s) and the source, provide a link to the Creative Commons license, and indicate if changes were made.

\section{References}

Arora P, Jain S, Sachdeva K (2013) Physical characterization of particulate matter emitted from wood combustion in improved and traditional cook stoves. Energy Sustain Dev 17:497-503

Bailis R, Ogle D, MacCarty N, Still D (2007) The Water Boiling Test (WBT) Version 3.0, Household energy and health program, Shell Foundation, p 38

Balakrishnan K, Sambandam S, Ramaswamy P, Mehta S, Smith KR (2004) Exposure assessment for repairable particulates associated with household fuel use in rural districts of Andhra Pradesh, India. J Expo Anal Environ Epidemiol 14:15-25

Berrueta VM, Medrano MS, Bustamante CG, Astier M, Masera OR (2017) Promoting sustainable local development of rural communities and mitigating climate change: the case of Mexico's Patsari improved cook stove project. Clim Change 140:63-77

Bharti SK, Kumar D, Anand S, Poonam BS, Kumar N (2017) Characterization and morphological analysis of individual aerosol of PM10 in urban area of Lucknow, India. Micron 103:90-98

Bonjour S, Adair-Rohani H, Wolf J, Bruce NG, Mehta S, Prüss-Ustün A, Lahiff M, Rehfuess EA, Mishra V, Smith KR (2013) Solid fuel use for household cooking: country and regional estimates for 1980-2010. Environ Health Perspect 121:784-790

Caroline C, Ochieng TC, Vardoulakis S (2013) A comparison of fuel use between a low cost, improved wood stove and traditional three-stone stove in rural Kenya. Biomass Bioenergy 58:258-266

Chafe Z, Brauer M, Klimont Z, Dingenen VR, Mehta S, Rao S, Riahi K, Dentener F, Smith KR (2014) Household cooking with solid fuels contributes to ambient PM2.5 air pollution and the burden of disease. Environ Health Perspect. https://doi.org/10.1289/ ehp. 1206340 
Cong Z, Kang S, Dong S, Liu X, Qin D (2010) Elemental and individual particle analysis of atmospheric aerosols from high Himalayas. Environ Monit Assess 160:323-335

Ezzati M, Mbinda BM, Kammen DM (2010) Comparison of emissions and residential exposure from traditional and improved cook stoves in Kenya. Environ Sci Technol 34(4):578-583

GBD 2016 Risk Factors Collaborators (2017) Global, regional, and national comparative risk assessment of 84 behavioral, environmental and occupational and metabolic risks or clusters of risks, 1990-2016: a systematic analysis for the global burden of disease study 2016

Gifford ML (2010) A global review of cook stove programs, unpublished MS Thesis, Energy and Resources Group UC, Berkeley 2(28): $\mathrm{p} 14$

Grandersona J, Sandhub JS, Vasquezc D, Ramirezc E, Smith KR (2009) Fuel use and design analysis of improved wood burning cook stoves in the Guatemalan Highlands. Biomass Bioenergy 33:306-315

Grieshop AP, Marshall JD, Kandlikar M (2011) Health and climate benefits of cook stove replacement options. Energy Policy 39(12):7530-7542

Hanber RD, Karve P (2002) National programme on improved chulha (NPIC) of the Government of India: an overview. Energy Sustain Dev 6(2):49-55

Herbert GMJ, Krishnan AU (2016) Quantifying environmental performance of biomass energy. Renew Sustain Energy Rev 59:292-308

Hieu NT, Lee BK (2010) Characteristics of particulate matter and metals in the ambient air from a residential area in the largest industrial city in Korea. Atmos Res 98:526-537

India Census, Fuel Used for Cooking (2011) [cited 10 Jan 2015]. Available from: http://censusindia.gov.in/

Jetter JJ, Kariher P (2009) Solid-fuel household cook stoves: characterization of performance and emissions. Biomass Bioenergy 33:294-305

Jetter J, Zhao Y, Smith KR, Khan B, Yelverton T, Decarlo P, Hay MD (2012) Pollutant emissions and energy efficiency under controlled conditions for household biomass cook stoves and implications for metrics useful in setting international test standards. Environ Sci Technol 46:10827-10834

Khandelwal M, Matthew E, Hill JR, Greenough P, Anthony J, Quill M, Linderman M, Udaykumar HS (2017) Why have improved cookstove initiatives in India failed? World Dev 92:13-27

Kim KH, Kabir E, Jahan SA (2016) A review on the distribution of $\mathrm{Hg}$ in the environment and its human health impacts. J Hazard Mater 306:376-385

Lombardi F, Riva F, Bonamini G, Barbieri B, Colombo E (2017) Laboratory protocols for testing of improved cooking stoves (ICSs): a review of state-of-the-art and further developments. Biomass Bioenergy 98:321-335

Lu S, Feng M, Yao Z, Jing A, Yufang Z, Wu M, Sheng G, Fu J, Yonenmochi S, Zheng J, Wang Q, Donaldson K (2011) Physicochemical characterization and cytotoxicity of ambient coarse, fine and ultrafine particulate matters in Shanghai atmosphere. Atmos Environ 45:736-744

Mansour MA (2016) Characteristics and risk assessment of heavy metals in airborne $\mathrm{PM}_{10}$ from a residential area of northern Jeddah City, Saudi Arabia. Pol J Environ Stud 25(3):939-949

Medina P, Berrueta M, Ruiz V, Edwards RD, Masera O (2017) Comparative performance of five Mexican plancha-type cook stoves using water boiling tests. Dev Eng 2:20-28
Mehetre SA, Sengar SH, Panwar NL, Ghatge JS (2016) Performance evaluation of improved carbonized cashew nut shell based cook stove. Waste Biomass Valor 7:1221-1225

Ming-Ho Y (2005) Environmental toxicology: biological and health effects of pollutants, Chap. 12, 2nd edn. CRC Press LLC, Boca Raton. ISBN 1-56670-670-2

Morais S, Costa FG, Pereira MDL (2012) Heavy metals and Human Health. In: Oosthuizen J (ed) Environmental health-emerging issues and practice, vol 10. InTechOpen, pp 227-246

Morman SA, Plumlee GS (2013) The role of airborne mineral dusts in human disease. Aeol Res 9:203-212

Murari V, Kumar M, Singh N, Singh RS, Banerjee T (2016) Particulate morphology and elemental characteristics: variability at middle Indo-Gangetic Plain. J Atmos Chem 73:165-179

Olujimi OO, Oputu O, Fatoki O, Opatoyinbo OE, Aroyewun OA, Baruani J (2015) Heavy metals speciation and human health risk assessment at an illegal gold mining site in Igun, Osun State, Nigeria. J Health Pollut 5:19-32

Panwar NL, Rathore NS (2008) Design and performance evaluation of a $5 \mathrm{~kW}$ producer gas stove. Biomass Bioenergy 32:1349-1352

Panwar NL, Kaushik SC, Kothari S (2011) Role of renewable energy sources in environmental protection: a review. Renew Sustain Energy Rev 15(3):1513-1524

Pardo M, Shafer MM, Rudich A, Schauer JJ, Rudich Y (2015) Single exposure to near roadway particulate matter leads to confined inflammatory and defense responses: possible role of metals. Environ Sci Technol 49:8777-8785

Pennise D, Brant S, Agbeve SM, Quaye W, Mengesha F, Tadele W, Wofchuck T (2009) Indoor air quality impacts of an improved wood stove in Ghana and an ethanol stove in Ethiopia. Energy Sustain Dev 13:71-76

Pipal AS, Jan R, Satsangi PG, Tiwari S, Taneja A (2014) Study of surface morphology, elemental composition and origin of atmospheric aerosols $\left(\mathrm{PM}_{2.5}\right.$ and $\left.\mathrm{PM}_{10}\right)$ over Agra, India. Aerosol Air Qual Res 14:1685-1700

Raman P, Murali J, Sakthivadevel D, Vigneswaran VS (2013) Performance evaluation of three types of forced draft cook stoves using fuel wood and coconut shell. Biomass Bioenergy 49:333-340

Ramji A, Soni A, Sehjpal R, Das S, Singh R (2012) Rural energy access and inequalities: an analysis of NSS data from 1999-00 to 2009-10. The Energy and Resources Institute TERI-NFA Working Paper No. 4, p 31

Ruiz-Mercado O, Masera H, Zamora SK (2011) Adoption and sustained use of improved cook stoves. Energy Policy 39(12):7557-7566

Sharma K, Singh R, Barman SC, Mishra D, Kumar R, Negi MPS, Mandal SK, Kisku GC, Khan AH, Kidwai MM, Bhargava SK (2006) Comparison of trace metals concentration in $\mathrm{PM}_{10}$ of different locations of Lucknow City, India. Bull Environ Contam Toxicol 77:419-426

Sielicki P, Janik H, Guzman A, Namiesnik J (2011) The progress in electron microscopy studies of particulate matters to be used as a standard monitoring method for air dust pollution. Crit Rev Anal Chem 41:314-334

Singh R, Barman SC, Negi MPS, Bhargava SK (2008) Metals concentration associated with repairable particulate matter $\left(\mathrm{PM}_{10}\right)$ in industrial area of eastern U.P. India. J Environ Biol 29(1):63-68

Singh S, Gupta GP, Kumar B, Kulshrestha UC (2014) Comparative study of indoor air pollution using traditional and improved cooking stoves in rural households of Northern India. Energy Sustain Dev 19:1-6 
Smith KR, Rogers J, Cowlin SC (2005) Household fuels and Ill-health in developing countries: What improvements can be brought by LPG?. World LP Gas Association and Practical Action, Paris, p 59

Srivastava A, Jain VK, Srivastava A (2009) SEM-EDX analysis of various sizes aerosols in Delhi India. Environ Monit Assess 150:405-416

Suresh R, Singh VK, Malik JK, Datta A, Pal RC (2016) Evaluation of the performance of improved biomass cooking stoves with different solid biomass fuel types. Biomass Bioenergy 95:27-34

Taner S, Pekey B, Pekey H (2013) Fine particulate matter in the indoor air of barbeque restaurant. Elemental composition source and health risk. Sci Total Environ 455:79-87

Venkataraman C, Sagar AD, Habib G, Lam N, Smith KR (2010) The Indian national initiative for advanced biomass cook stoves: the benefits of clean combustion. Energy Sustain Dev 14:63-72
Wang X, Bi X, Sheng G, Fu J (2006) Hospital indoor $\mathrm{PM}_{10} / \mathrm{PM}_{2.5}$ and associated trace elements in Hunangzon, China. Sci Total Environ 366:124-135

World Health Organization (2010) WHO guidelines for indoor air quality: selected pollutants. World Health Organization, Geneva

World Health Organization (2014) Burden of disease from household air pollution for 2012. World Health Organization, Geneva

World Health Organization (2016) Household air pollution and health. Fact sheet 292. World Health Organization, Geneva

Yue W, Li X, Liu J, Li Y, Yu X, Deng B (2006) Characterization of $\mathrm{PM}_{2.5}$ in the ambient air of Shanghai city by analyzing individual particles. Sci Total Environ 368:916-925 